\title{
Enoch Powell: The lonesome leader
}

\author{
Ben Wellings
}

\section{Introduction}

By all accounts Enoch Powell was not someone you would warm to, but his personal awkwardness was offset by his enduring popular appeal - a charisma that enabled support for his political causes to cross class boundaries and party affiliations. Despite his education and erudition - or perhaps because of it he appealed to the working classes and Labour voters, and appeared as a man speaking truth unto power, unafraid to break the political taboos of the day and thereby appealing to individuals who similarly felt silenced by political developments. Therefore his mass appeal lay in his projection of himself as an outsider: the middle-class parvenu surrounded by Tory grandees; the spokesman for the oppressed white majority; the lone voice against Europe in the Conservative Party; the defender of Protestant Ulster's freedom. Support for such causes may have been the death knell for his leadership ambitions, as he was unable to make the enduring connections necessary for such a role; however, his leadership existed in a less formal sense than through a political party or government. Powell's political appeal lay in the fact that he was a selfconsciously lonesome leader.

We can view Powell as both an exemplar and an articulator of a post-imperial English nationalism, but one deeply rooted in the experience of empire. Here, then, is what Jonathan Hearn has referred to as the 'ecology' of Powell's national identity and indeed his nationalism. Hearn argues that 'the relationship between categorical and personal identities will always be mediated by intervening forms of social organisation'. ${ }^{1}$ For Powell, these social categories meditating his sense of national self were empire, state and locality. But here we run into a difficulty in examining English nationalism through a biographical approach to Enoch Powell: Powell not only identified strongly with England, but he also expressed it for others. To paraphrase Hearn, he fused his individual agency with the larger agency of the nation. ${ }^{2}$ But this was not merely an individual quest for power within one's life. Powell sought to mobilise the English and British nation for political ends at a distinct moment in political time when previous national narratives were in flux. Powell self-consciously moved 'against the

1 Hearn, this volume.

2 Ibid. 
historical flow', talking of England as a nation nearing the end of its natural life and crucially under threat. But he also cast himself 'against the flow' of other social categories, notably party, in order to increase his popular appeal. Thus, his political charisma - in distinct contrast with his personal charisma-lay in an ambivalent relationship to the 'ecology' in which he operated: strongly influenced by a brief experience of empire, a deep veneration of the English state, but breaking free of the confines of party and living the life of a political loner in order to speak for the nation.

\section{The Myth of Powell}

On 25 February 1974, John Enoch Powell rose to address an audience in Saltaire in Yorkshire. On this occasion he commanded an audience of an estimated 1000 people with another 1000 having been turned away. One older member of the audience claimed to have walked six miles to see Powell speak. ${ }^{3}$ This was a large audience for someone who was formally outside politics, having stood down as MP for Wolverhampton South-West at the beginning of the month. But in the previous six years, Powell had become one of the best-known and most controversial political figures in British politics. The audience cheered him and chanted his name as he rose to speak for the second time in a week on his decision to oppose the party he had been a member of only weeks before. The issue was Britain's membership of the European Economic Community (EEC), the advent of which Powell could not reconcile in his conscience. This was the issue that led to his decision not to stand for re-election and indeed to advocate voting for the Labour opposition on polling day. But as he began to speak, a heckler from the audience yelled 'Judas!' 'Electrified, Powell pointed to him. He shouted back: "Judas was paid! Judas was paid! I am making a sacrifice."”4

This incident during the general election campaign of February 1974 is indicative of Powell's political charisma and his ability to mobilise opinion - or at least strongly cohere sections of the public - with his ideas and rhetoric. The intensity of feeling in the hall that night spoke to the support he had gained for himself and his ideas during his political career, but especially since his infamous 'Rivers of Blood' speech to the West Midlands Conservative Association in April 1968. The presence of a heckler, however, offended by his betrayal of the Conservative Party also attested to his divisiveness and not just amongst

3 Warman, C. 1974, 'Mr Powell reafirms EEC call but says "I shall die Tory"', The Times, 26 February 1974. 4 Cited in Heffer, S. 1998, Like the Roman. The life of Enoch Powell, Weidenfeld \& Nicolson, London, p. 704. A similar account of this incident is given by Cosgrave alongside a photograph of Powell in full verbal flood, although The Times from 26 February played down Powell's emotive response and said that he responded to the heckler with the same retort but 'grimly'. Cosgrave, P. 1989, The Lives of Enoch Powell, The Bodley Head, London. 
political opponents on the left. His response to the heckler also demonstrated a command of biblical knowledge that befitted a classical scholar and translator of the New Testament from Greek and a man who liked to wear his learning on his sleeve. His superior knowledge of the scene at the Garden of Gethsemane trumped his interlocutor and drew a rapturous response from his audience. In an instant it also refashioned Powell from the Betrayer to the Martyr.

This image of the brilliant yet persecuted loner outside the walls of party and answerable to nothing but his conscience was an essential part of Powell's appeal. His charisma lay in his combination of logic and professorial analysis along with his emotional response and intensity of feeling towards certain issues. Combining this charisma with issues that were popular and populist, Powell drew support from across class and political cleavages and in doing so outlined a vision of the nation. But this vision was not one without contradictions. Powell's logic and political style - or naivety - did not allow him to lead from within government. Importantly, if the balance between professorial logic and emotion was out in his thinking and rhetoric, his popular appeal diminished. Neither was he always able to translate his intellectual reasoning into political action with a mass appeal. Instead his popular appeal rested on him being the outsider 'going against the flow', a loner, leading a national community.

Enoch Powell died on 8 February 1998. The following morning The Sun said:

He always said what people in power didn't want to hear. That was because Enoch Powell was almost always right. His death robs the country of one of the finest Conservative thinkers in history. Enoch didn't care who he upset if he believed something needed to be said. What a change from today's fawning Yes-men. ${ }^{5}$

The Sun's bite-sized opinion encapsulated what we might call the 'myth of Powell': a narrative that aligned the wider social category of the nation with a widespread understanding of Powell's role in public life. In this narrative, Powell was a thinker, a man of conscience and a man unsullied by the grubby compromises of quotidian politics. There is truth in all of this, although these qualities may not have made Powell a brilliant politician. But there can be no denying his impact on British politics in his day, or his continuing appeal amongst some members of the community. Margaret Thatcher described Powell as 'magnetic', adding that 'there will never be anybody so compelling'. ${ }^{6}$ His most recent biographer, Simon Heffer, argued that 'Powell's contribution to British national life was greater and longer-lasting than most executive action

5 'The Sun says...', The Sun, 9 February 1998.

6 Wooding, D. 1998, 'Maggie's tribute as Enoch dies at 85', The Sun, 9 February. 
could ever be. His effect on the thinking of others, from the highest ministerial level down to the British elector, was perhaps more profound than that of any other practicing politician of the twentieth century. ${ }^{7}$

These assessments of Powell - only two amongst many - attest to the way in which he became a tribune for a new articulation of English nationalism, a nationalism that was both post-imperial and rooted in the experience and assumptions of England's past. But even more than this, Powell actually embodied and lived English nationalism even as he acted it out. Powell experienced the Empire at the moment of its passing. Much of his political life was spent in an attempt to work out a coherent and consistent framework for English nationalism within a post-imperial British framework. Powell's nationalism was both intelligent and narrow-minded; it was articulate, expressed with panache and at times spiteful. It was this attempt at a consistent underlying logic-unusual in British conservatism - which led him towards positions and statements that would challenge his party loyalty and make his continued membership of the Conservative Party untenable. But the consequences of this unyielding logic and Powell's subsequent alienation from potential supporters added to his aura as a man of principle placing nation before party and personal interest, or, as Powell liked to put it, subsuming the part to the whole.

Powell's own actions put him at odds with many if not most of his colleagues and contributed to his 'lonesomeness', which in turn fed into the 'myth of Powell'. This lonesomeness inspired respect and frustration in equal measure. Even those opposed to Powell's views could register admiration for the man, usually predicated on his intellectual honesty. In the wake of the 'Rivers of Blood' speech, Vidya Anand and F. A. Ridley wrote of Powell's 'deserved reputation for his outstanding intellect and his political sagacity' ${ }^{8}$ Similarly, Paul Foot, whilst portraying Powell's Birmingham speech as an attempt to harness racist attitudes to help Powell win the leadership of the Conservative Party, could admire the way in which Powell cooperated with an obviously hostile commentator in the preparation of his Penguin Special on Powell and immigration, an attribute that made him stand out against some of his party colleagues. ${ }^{9}$ On the other hand, otherwise sympathetic observers such as Patrick Cosgrave could not help but notice that Powell was not the easiest of people to work with. 'In no ordinary sense of the word', wrote Cosgrave, 'could Powell be called a good colleague. His interpretation of his duty, exact and honourable as it was, was at least gnomic, if not even Jesuitical.' ${ }^{10}$ Part of the reason for his expulsion from the Shadow

7 Heffer, Like the Roman, p. 958.

8 Anand, V. and Ridley, F. 1969, The Enigma of Enoch Powell. An essay in political realism, Medusa Press, London, p. 9.

9 Foot, P. 1969, The Rise of Enoch Powell, An examination to Enoch Powell's attitude to immigration and race, Penguin Books, Harmondsworth, UK, Preface.

10 Cosgrave, The Lives of Enoch Powell, p. 228. 
Cabinet in April 1968 was the declaration of two senior colleagues to the party leader that they would no longer work with Powell. Powell's fall from grace might suggest another interpretation away from Anand and Ridley's view of him as a 'political maestro' and tend in the direction of some sort of political naivety whereby the pursuit of logic and consistency was a death knell for his political ambitions (but not his popular appeal). So his sacking from the Shadow Cabinet freed him from the constraints of collective responsibility and pushed him closer to 'the people' on whose behalf, from this point on, he began to speak.

So in assessing Powell's impact on the mobilisation of English nationalism as a political force in the late 1960s and early 1970s, we cannot divorce his personal identity from the issues that he espoused. Powell's vision of the nation coalesced around four main issues: free-market neo-liberalism; opposing Britain's part in the process of European integration; a defence of Northern Ireland's integration within the United Kingdom; and anti-immigration. It was around the last issue that Powell had the greatest impact.

Postwar Britain experienced a labour shortage. During these years of austerity, many Britons migrated in the hope of a better future for themselves and their children. This population outflow exacerbated a labour shortage created by the demands of postwar reconstruction. The answer to this shortage was to bring in labour from the so-called New Commonwealth: essentially the 'nonWhite Dominions' of the former empire. In a legal sense, migration to Britain was fairly straightforward since, until 1962, any subject of the Crown had the right of residence and employment in the United Kingdom. But in that year, the Conservative Government sought to restrict this inflow of 'coloured' labour. In the general election of 1964, the issue of race relations made an appearance in the constituency of Smethwick. But the issue of race really came to a head in 1968 over the Labour Government's plans to introduce a Race Relations Bill.

Unlike Paul Foot's analysis that Powell crudely used racism as part of an attempt to win the leadership of the Conservative Party from Edward Heath, it seems as if Powell had made some speeches about immigration in the years before 1968. The speech he gave to the West Midlands Conservative Association in Birmingham on Saturday, 20 April 1968 was, however, quite different to any of his previous forays into the subject. In this speech, Powell mixed population projections based on figures gleaned from the Registrar-General with unsubstantiated anecdote: a perfect mixture of Powell's emotion and logic. The speech was destined to attract press attention as it seemed to stray off Powell's defence portfolio and last, and importantly, it was recorded on film. The vision of Britain contained in the speech was apocalyptic, conjuring visions of the slave revolts of the nineteenth century. 'In twenty years time', Powell relayed from an unnamed constituent, 'the black man will have the whip-hand over the 
white'. ${ }^{11}$ He went further in relaying the story of an elderly woman forced to move from her house, taunted as a 'racialist' by 'wide-grinning piccaninnies', situating the defence of British sovereignty right into the streets and homes of white people in his constituency of Wolverhampton South. He concluded that Britain as a nation must be 'literally mad' to allow continued immigration and defend the rights of such immigrant groups with instruments such as the proposed Race Relations Bill currently before Parliament.

The speech created a political uproar. Powell was sacked from the Shadow Cabinet the following Sunday evening. But the speech, and Powell's sacking, also mobilised support for him across existing political and class boundaries, establishing that Powell was most politically appealing as an outsider. On Tuesday, 23 April, dockers from London's West India docks went on strike and marched in support of Powell's right to 'free speech', immediately identifying Powell as a lone voice within the political Establishment. ${ }^{12}$ The following day meat packers from Smithfield market struck and marched to the House of Commons, presenting Powell with a 92-page petition in his support. Letters flooded into his London home at the rate of four or five sacks per delivery, amounting to a total of about 40000 letters within four days, of which Powell claimed that only about a dozen were opposed to his views. ${ }^{13}$ Powell's speech gained support from other anti-Establishment figures on the right, beginning the sense that Powell might be a sophist, but his political constituency was right-wing populist and radical. Policy Director of the newly formed National Front, A. K. Chesterton, claimed that Powell's views did not vary in any way from those of the National Front, whilst Oswald Mosley claimed that Powell was only saying what Mosley himself had said nine years earlier. ${ }^{14}$ At the end of a giddying week in politics, The Times commented that '[o]ver the past six days, Mr Powell has stirred the national emotions more than any other single politician since the war' ${ }^{15}$ But aside from this potential rupturing of support for a Labour government and legitimisation of views held by the extreme right, the greatest immediate impact was on the Conservative Party. Tory leader, Edward Heath, initially struggled to balance support for Powell over immigration whilst maintaining party unity. Powell's sacking in April resolved this problem in the short term, but set a precedent for subsequent action regarding European integration: a principled stand followed by more effective politicking free from Cabinet or party constraints. Powell's stance appealed to the right wing of the Conservative Party, in particular the Monday Club, whom he addressed in November 1968. On 12 February 1969, Powell and Duncan Sandys introduced a bill seeking to amend the immigration

11 Cited in Lord Howard of Rising (ed.) 2012, Enoch at 100. A re-examination of the life, politics and philosophy of Enoch Powell, Biteback Publishing, London, p. 173.

12 'Dockers march for Powell', The Times, 24 April 1968.

13 'Mounting volume of race protest. 40,000 Powell postbag', The Times, 25 April 1968.

14 Labour Research Department 1969, Powell and His Allies, LRD Publications, London, pp. 15-16.

15 Trethowan, I. 1968, 'Mr Enoch Powell: a Cromwell or a Goldwater?', The Times, 26 April 1968. 
laws by restricting the right of dependants of migrants to entry to the United Kingdom, supported by a significant number of senior Conservatives including the up-and-coming Margaret Thatcher. ${ }^{16}$ Powell's legacy, however, may well have been beneficial in electoral terms: an NOP survey during the 1970 election found that 18 per cent of usually Labour voters said they had voted Conservative because of Powell and a further 22 per cent had considered doing so. ${ }^{17}$

Another issue over which Powell was outspoken and garnered popular support was Britain's part in the deepening process of European integration focused on negotiations for the United Kingdom's accession to the EEC and the referendum on Britain's continuing participation in the Common Market in 1975. Here again, Powell was out of step with his party; indeed he resigned from the Conservative Party ahead of the February 1974 election since he could not endorse Britain's membership of the EEC. He went so far as to urge the electorate to vote Labour since that party at least might hold a referendum on continuing membership, implying in a televised interview on 26 February that he had already done so himself by postal vote. ${ }^{18}$ Again we see Powell's strong identification with the nation coupled with the need to have himself expelled from political organisations in order to act upon matters of principle. The Common Market issue and his stance on it allowed Powell to further articulate his vision of the nation as irrevocably linked with the enduring sovereignty of the Crown-inParliament as well as to place himself again in the position of the loner and man of principle who always put nation before party. Although no longer a candidate standing for Parliament, Powell could still draw crowds greater even than the Leader of the Opposition and his erstwhile chief, Edward Heath. ${ }^{19}$ By the end of the election campaign, Powell felt he could not remain silent on the threat posed to the sovereignty of the Crown-in-Parliament by Britain's membership of the EEC. Accordingly, he re-entered the political fray, simultaneously placing himself at odds with Edward Heath and putting nation before party. At Saltaire in Yorkshire on the night of 25 February, Powell defended his decision to vote Labour. Claiming that the defence of Britain's national and political inheritance had never been the preserve of one party alone, Powell declared '[i]n that defence a citizen may without inconsistency or discredit stand side by side with those from whom on lesser matters, however important in themselves, he totally dissents' ${ }^{20}$ With regard to the Prime Minister and Leader of the Opposition, he added in eloquent yet populist tones that

the miracles of tergiversation which the present Administration has accomplished leave nothing to admire cessors in that department. In

16 Labour Research Department, Powell and His Allies, p. 22.

17 Cosgrave, The Lives of Enoch Powell, p. 289.

18 Sweeney, C. 1974, 'Mr Powell has voted by post for Labour', The Times, 27 February 1974.

19 Warman, The Times, 26 February 1974.

20 Ibid. 
the prowess of their predeacrobatics the previous Prime Minister [Harold Wilson] for all his nimbleness and skill is simply no match for the breathtaking, thoroughgoing efficiency of the present one [Edward Heath]. ${ }^{21}$

As in 1970 when it seemed that Powell helped win the election for the Conservatives, it seemed that in February 1974 Powell foiled Heath's attempt to form a parliamentary majority, opening the way for Wilson to form a minority government in March.

There were, however, severe limits to Powell's appeal, partly to do with the translation of his personal identity into his political one. What emerges from a consideration of the issues of immigration and European integration was that Powell was articulating a vision of the English nation predicated upon a defence of (Crown-in-Parliament) sovereignty, but it was a vision of the nation in which his charisma, personality and logical approach to issues also prevented him from broadening his support base. Indeed, in the early 1970s there were some tonguein-cheek references to Wolverhampton-les-deux-Eglises, a reference to General de Gaulle's residence to which he retreated before assuming leadership of the Fifth Republic in 1958. Powell's precocious belief in a neo-liberal and deregulated economy, however, did not allow him to make quick common cause with the dockers or mobilise the meat packers in April 1968. When presented with the petition by the striking Smithfield workers outside Parliament, Powell thanked them but discouraged them from taking further industrial action, advising them to write to their MPs instead. Here was an example of how Powell's logic on race and industrial relations - both internally coherent - clashed. But although these fears of Powell as a latter-day de Gaulle or Mosley can be understood, there were certain contradictions that arose from Powell's unusually logical approach to the nation, which resulted in the vision of England bequeathed to posterity by Powell being close to his own political personality and profile: readily articulated, somewhat resentful and not quite part of the mainstream but always present in the wings.

To understand why this was the case, we need to examine Powell's vision of England. Powell's thinking about the nation had cohered somewhat since the mid 1950s when he co-authored a book with Angus Maude entitled Biography of a Nation: A short history ofBritain. In the introduction, Powell and Maude run up against the illogical and subjective bulwarks of the nation. 'There is no objective definition of what constitutes a nation', they wrote:

It is that which thinks it is a nation. Race, language, geography-none of these is conclusive. If geography made a nation, there would not be 
two nations in Ireland today. If identity of language were the key, the Swiss would not be one nation, yet they are. As for race, Hitler looked for it as a basis of nationhood, with all that was left of German learning and science to help him, but failed to find it. ${ }^{22}$

In short, they concluded that '[n]ations are the units of mankind as a political animal'. ${ }^{23}$ Yet to this ultimately political definition was added a biological one, the refutation of Hitler's racism notwithstanding: 'Yet however intensively it is studied, this phenomenon of national consciousness in mankind remains almost as mysterious as that of the life of the individual organism. ${ }^{24}$ His and Maude's history of Britain was almost elegiac, concerning itself with the way that

the consciousness of being a nation began among the English; how it grew and changed, embracing with various intensity and various meaning the inhabitants not only of these islands but of countries and continents across the world; and how that consciousness is now waning and its limits shrinking as if some natural span were nearing its close. ${ }^{25}$

As the 1950s wore on, Powell sharpened his concept of the nation and-in England's case at least - linked it to a certain vision of homogeneity under the Crown-in-Parliament. Writing in the National and English Review in August 1958, Powell reflected on his sojourn in Australia as Professor of Greek at Sydney University in the late 1930s and commented on the White Australia Policy, which had underpinned Australia's national imaginings since Federation in 1901: 'Finding herself providentially lacking the elements of racial division, yet able to achieve her national development without creating them', wrote Powell, 'Australia would be worse than foolish if she did not jealously preserve the advantage of an all-white population', adding that 'there will be problems enough in the assimilation of the "new Australians" from Europe' ${ }^{26}$ But by the 1960s, Australia and Britain were different in many regards: in Australia the mood was one of optimistic national development, whereas Powell believed that Britain was gripped by a resignation to relative decline. It was this resignation that, in his view, was blighting politics and the national spirit:

The British are a parliamentary nation: internally and externally they are conditioned and defined by that institution and that historical experience. If our values are in danger, and if our freedom and

22 Maude, A. and Powell, E. 1955, Biography of a Nation: A short history ofBritain, Phoenix House, London, p. 7.

23 Ibid., p. 7.

24 Ibid., p. 8.

25 Ibid., p. 9.

26 Powell, E. 1958, 'Development down under', National and English Review, August, pp. 67-70. 
independence are in danger, it is because Parliament is endangered, and endangered in the only way an institution can be- by inner loss of conviction. ${ }^{27}$

Powell came to believe that the way to prolong England's natural span was to reverse the inner loss of conviction and defend it from threats inside and out. More and more he linked the nation with homogeneity under the sovereignty of the Crown-in-Parliament. The link between the threat to Parliament's sovereignty and the provisions and finalite of the Treaty of Rome are easy to discern. Powell outlined them in one of his first speeches against the Common Market in Smethwick during 1969:

The precondition for any political unity is the subordination of the parts to the whole. Short of force, this can only come about through a section settled and deep instinctive conviction felt by those concerned that they belong first and foremost to the whole and that its interest[s] override those of the parts. Unless and until that conviction exists, democratic or representative institutions are unworkable. On the other hand, without such institutions, the acts of sovereignty, which a political unit must perform on behalf of all its members and binding on all its members, would be intolerable and unacceptable. ${ }^{28}$

This similar logic of homogeneity also informed some of his thinking regarding the consequences of immigration, or more particularly, the concentration of immigrant communities in England's cities. Speaking to the Monday Club in April 1976, Powell logically imagined a homogenous immigrant community in parliamentary political terms. If 5 per cent of the population was 'coloured' or 'black', Powell mused, adding 'it tends to be brought under one single classification in order to enhance its leverage', then in a quota system it would require $32 \mathrm{MPs}$ - more than the Scottish National Party, Plaid Cymru, the Ulster Unionist Party and Liberals combined. Powell went on:

I need not follow the analysis further in order to demonstrate how parliamentary democracy disintegrates when the national homogeneity of the electorate is broken down by a large and sharp alteration in the composition of the population. While the institutions and liberties on which British liberty depends are being progressively surrendered to the European superstate, the forces which will sap and destroy them from within are allowed to accumulate unchecked. ${ }^{29}$

27 Cited in Ritchie, R. 1978, Nation or No Nation? Six years in British politics, BT Batsford, London, p. 134. 28 Powell, E. 1969, Speech on the Common Market to a public meeting at the Warley College of Technology, Smethwick, 5 September 1969, Anti-Common Market League, London.

29 Cited in Ritchie, Nation or No Nation, p. 166. 
More and more, Powell was guided by emotion rather at the expense of the logical precision that even his detractors had admired in the 1960s. In 1988 Powell estimated that 'in the foreseeable future' (again displaying what was becoming an uncharacteristic lack of precision on this subject), the 'New Commonwealth' ethnic population will represent one-third or more of the population of inner London and other cities in England. This will be more than sufficient to secure effective political control locally and nationally 'by dint of its distinctiveness and solidarity', and this point could not be reached 'without civil strife of a degree that makes it indistinguishable from civil war' ${ }^{30}$ This lack of precision - the emotion minus the logic compounded by hyperbole- had the effect of leaving his core support unchanged, but allowed his opponents more and more room to attack the basic assumptions of his arguments.

The logic of cleaving closely to a Parliamentary definition of nationhood was now skewing the analysis. In such a manner did Powell's charisma start to break down. Much of his appeal rested on the combination of logic and emotion giving him the aura of being 'almost always right', to quote The Sun's obituary cited above. But when these two elements were decoupled, the spell weakened and all that was left was an emotive man speaking out in what seemed to those unimpressed by his use of language, history and numbers a nasty advocacy of what we would today call ethnic cleansing. Furthermore, defending the unity of parliamentary sovereignty in Ulster may have been sound reasoning, but it was not good politics from the point of view of mass mobilisation in England. Indeed his adherence to Crown-in-Parliament sovereignty arguably weakened his ability to mobilise popular sovereignty. Powell was indeed populist, as many had long realised. 'Powellism is a subtly constructed appeal', wrote the Sunday Times Magazine on 29 December 1968:

It is populist and more. It will unite Mrs Mary Whitehouse, the old lady who campaigns against electricity pylons or tree fellers, the resentful poor, the racialist poor, the red-tape haters, the weak, the halt and the lame. All those who hunger for a good thumping cause, country and flag. ${ }^{31}$

But at the same time, Powell struggled to reconcile what Tom Nairn identified as 'the necessary resort to populism' in nationalist mobilisation ${ }^{32}$ with the sovereignty of Parliament. Speaking at Chester-le-Street in January 1972, Powell told his audience that '[t]he power is still the people's if they have the will

30 Cited in Lewis, R. 1988, Anti-Racism. A mania exposed, Quartet Books, London, un-numbered page in introduction.

31 Cited in Labour Research Department, Powell and His Allies, p. 23.

32 Nairn, T. 1981 [1977], The Break-Up of Britain. Crisis and neo-nationalism, New Left Books, London, p. 339. 
to use it' ${ }^{33}$ But Powell couldn't divorce this incipient 'People Power' from his understanding of Parliament and a Burkean view of representative democracy. As far as Powell was concerned, the development of the EEC was a direct threat to the nation since it was a threat to Parliament. This fact can explain some of Powell's initial prevarication over whether or not to support a referendum on EEC membership. Eventually, though, Powell supported a referendum, thereby undermining the sovereignty of the institution that he sought to defend.

But if his logical drive to defend the nation by defending Parliament through a referendum was straining even Powell's intellectual abilities, there were other areas where his personality and logical approach undercut his potential mobilisation of English nationalism. The first of these was the fact that Powell was not a 'clubbable' man. This meant that what could seem like a principled stand by a lone tribune actually translated into an unwillingness to work with other people - and the feeling was often mutual. This 'aloneness' meant that Powell was not able to form the necessary political alliances that would have enabled him to fully capitalise on his popularity post 1968. As the campaign to derail the accession to the Treaty of Rome grew in Parliament in the early 1970s, Nigel Spearing MP assessed Powell's likely actions in a letter to Labour AntiMarketeer Peter Shore:

It would therefore seem likely that [Powell] will launch an individual anti-market campaign...This could be either chauvinistic, or more likely on post-imperial criteria. I suggest that his Indian background is a very important influence. If Powell believes what he says, and I think he does, he will try to destroy Heath rather than see us sign the Treaty. ${ }^{34}$

This excerpt also points to other dimensions of Powell's attitudes and actions that could be perceived as principled stands but which had more prosaic roots. Powell was only human and part of his antipathy towards the EEC was that it was the pet project of Edward Heath. Powell hated Heath and the feeling was mutual (Heath's silence when Powell died in 1998 was deafening). So what was in part a clash of ideals over the future of Britain and the lessons to be learned from Europe's past was also in considerable part a clash of personalities.

Powell's self-presentation as a loner was good for his persecuted image; his principled stand on particular issues was a similarly important plank of his charismatic appeal, but it was not necessarily good politics. In certain ways, then, Powell, if not exactly the 'Patron Saint of Lost Causes', could more plausibly be described as the 'Patron Saint of Rearguard Actions'. Nor did Powell offer a compelling vision of Britain's future, except one rooted in England's past.

33 Powell, E. 1973,Common Market: Renegotiate or come out, Elliot Right Way Books, Kingswood, UK, p. 118. 34 Spearing, N. 1971, Letter to Peter Shore MP, 31 May 1971, British Library of Political and Economic Sciences, SHORE/9/44 [Miscellaneous, 1971]. 
Such then is the enigma of Enoch Powell: of an intellectually brilliant man and a political maestro seeking at once to lead contemporary Britain in two ways, both new and old. ${ }^{35}$

Similarly, Powell's seeming mass appeal needs to be closely examined. Whilst it is true that there were strikes and marches in support of Powell's 'right to free speech' on the issue of immigration and race relations in 1968, there were also demonstrations against Powell and his views. Tony Barrett, a spokesman at the Tilbury Docks, stated that 'many dockers are disgusted by the support shown to Mr Powell'. ${ }^{36}$ The actions of Ray Campbell supporting those marching for Powell should give us pause, too. Campbell, described by The Times as 'a West Indian', told its reporter that 'I do not agree with what Mr Powell said, but the men are my mates and they treat me alright. I'm going out with them to show support for the union. ${ }^{37}$ This evidence alone shows that there were dynamics at play other than the force of Powell's ideas alone.

And then there was the hostility to Powell and the implication of his ideas. The 'Rivers of Blood' speech caused a storm of controversy. The Reverend Canon Mark Green feared for the effects of such attitudes on society, and asked rhetorically 'are we simply to tear up all [the New Testament] says about the reconciliation of races?'38 And whilst Powell's historical memory was filled with the development and expansion of the institutions of British representative government, other observers' view of history was more contemporary. One former Conservative MP, Humphrey Berkeley, said that Powell's speech was 'the most disgraceful public utterance since the days of Sir Oswald Mosley', ${ }^{39}$ which put him in common cause with Frank Cousins, General Secretary of the Transport and General Workers Union, who reminded strikers that before the war the dockers were the ones who marched against the Blackshirts. ${ }^{40}$

In short, Powell's views and style were ultimately too divisive to mobilise a broad and enduring national base, and his logical defence of Crown-inParliament sovereignty shied him away from any Gaullist authoritarianism. Certainly Powell was able to cohere a significant section of the electorate around issues such as immigration, Europe, taxation and the economy. His principled defence of parliamentary sovereignty in Ulster gained him support, too, but far less so in England. Furthermore, Powell's ideas had a legacy that was taken up by others in the Conservative Party, and his status as the conscience of the party was strong during the years of Thatcherite ascendency. Many of his causes

35 Anand and Ridley, The Enigma of Enoch Powell, p. 23.

36 'Dockers march for Powell', The Times, 24 April 1968.

37 Ibid

38 Green, M. 1968, 'Letter to the Editor', The Times, 29 April 1968.

39 'Mosley speeches recalled', The Times, 22 April 1968.

40 'Mounting volume of race protest. 40,000 Powell postbag', The Times, 25 April 1968. 
were championed between 1979 and 1990, but many were not (or rather the ideas were championed but the policy actions spoke differently). A free-market economy was implemented by the Thatcherites, who also took a hard line on immigration. But only in Thatcher's later years as Prime Minister did she adopt a Powellite line on Europe, and with disastrous results for her and her party after she left Downing Street in 1990. Ulster was not treated as an unequivocally integral part of the United Kingdom after 1985. The final failure of Powell's mass mobilisation was signalled by the Conservative Party leadership under David Cameron as it positioned itself for government between 2005 and 2010. In 'detoxifying' the Conservative brand and attempting to redress the image of the Tories as a 'nasty' party, Cameron was quick to move away from the 'toxic trio' of policy issues: immigration, Europe and tax. ${ }^{41}$

Powell was a divisive figure and his obituaries are a testament to that. Former chancellor Norman Lamont described him as 'the greatest politician of my lifetime... g genuine giant amongst pygmies'. But Denis Healey had a different view:

Enoch was an intellectual in the worst sense of the word. He would pursue everything to its logical conclusion, even if it made political nonsense... The best thing he ever did was marry Pamela who is a very nice human being. Enoch was a bit short on the human side. ${ }^{42}$

These views encapsulate some of Powell's charisma and also why Powell failed to mobilise English nationalism in an enduring way. His personal appeal was based on his combination of logical precision and emotional engagement with causes he clearly felt passionate about. This logical approach to politics forced him out of government and led him to adopt causes that were not politically advantageous in the formal career sense, but which gained him wide support in the country. This tendency also led him to be perceived as a loner outside the constraints of politics at a time when principle seemed in short supply. But there were tensions in his logical approach to English nationalism, most specifically in the relationship between popular and parliamentary sovereignty, tensions that reduced the logical consistency of Powell's approach and thereby some of his appeal. Furthermore, as many people were repelled by Powell's ideas as were attracted to them. Since his ideas were put forward with such eloquencethough at times the sophistry obfuscated as much as it illuminated-there was much for his critics to attack, and the cold logician could repel as well as attract, inhibiting Powell from building important and enduring political alliances related to his causes. And even though the issues he chose, especially immigration and race, resonated with a broad base, ultimately he could cohere

41 Bale, T. 2010, The Conservative Party from Thatcher to Cameron, Polity, London.

42 Lamont, N. and Healey, D. 1998, 'Hero and villain: opinion', The Sun, 9 February 1998. 
only a core group of supporters who saw in Powell a far-sighted man of principle whose stance caused him to remain the outspoken, yet lonesome, tribune of the English nation. 